\title{
Vitrification of GV-porcine oocytes by 1-, 2-, and 7 -step saturation in ethylene glycol
}

\author{
V. Isachenko ${ }^{1,3}$, Eugenia Isachenko ${ }^{2}$, F. Perez-Sanchez ${ }^{3}$ and C. Soler ${ }^{3}$
}

\author{
'Department of Animal Reproduction. Institute for Animal Science \\ P.O.Kulinichi, 312120 Kharkov, Ukraine \\ 'Department of Human Reproduction, \\ Institute for Problems of Cryobiology and Cryomedicine. \\ Perejaslavs'ka 23, Kharkov, Ukraine \\ ${ }^{3}$ Department of Animal Biology, Valencia University \\ Dr. Moliner 50, 46100 Burjassot, Catalonia
}

(Received 11 September 1997; accepted 25 March 1998)

\section{ABSTRACT}

Three experiments were conducted to investigate the effect of 1-, 2- and 7-step saturation with cryoprotectant on vitrification of germinal vesicle porcine oocytes to M-II stage. In Experiment I non-cooled cumulus-oocyte complexes (COCs) were equilibrated in ethylene glycol (EG) using a single-step or step-wise protocol, EG was removed by single-step or step-wise procedure with all manipulations being performed at $42^{\circ} \mathrm{C}$. In Experiment II non-cooled COCs were equilibrated in ethylene glycol (EG) using the single-step or step-wise protocol with further EG removal by the single-step or step-wise procedure and pretreatment with Cytochalasin B. In experiment III, performed taking into account the results of Experiments I and II, a total of $177 \mathrm{COCs}$ were divided into three treatment and one control groups. All treatment COCs were vitrified after pretreatment with Cytochalasin $\mathrm{B}\left(5 \mu \mathrm{g} / \mathrm{ml}\right.$ at $38.5^{\circ} \mathrm{C}$ for $\left.10-15 \mathrm{~min}\right)$, direct plunging into liquid nitrogen, thawing for $5 \mathrm{sec}$ in a waterbath at $50^{\circ} \mathrm{C}$, removal of the cryoprotectant by exposure to $1 \mathrm{M}, 0.75 \mathrm{M}, 0.5 \mathrm{M}, 0.25 \mathrm{M}$ for $4,2,2$, and $2 \mathrm{~min}$ respectively at $40-42^{\circ} \mathrm{C}$. Group 1 COCs $(n=52)$ were cryopreserved after exposition to $40 \% \mathrm{EG}$ for $4 \mathrm{~min}$. Group $2 \mathrm{COCs}(\mathrm{n}=47)$ were exposed to $25 \% \mathrm{EG}$ for 5 min and then to $40 \% \mathrm{EG}$ for $30 \mathrm{sec}$ prior to vitrification. Group $3 \mathrm{COCs}(\mathrm{n}=48)$ were equilibrated over 13 min using a series of EG concentrations $5,10,15,20,25,30$, and $40 \%$ EG for $5,2,2,2,1,0.5$, and 0.5 min, respectively. Group $4 \mathrm{COCs}(\mathrm{n}=30)$ were control oocytes (not exposed to $\mathrm{EG}$ and not frozen). After thawing and passage through the sucrose series (treatment) or without treatment (control) $\mathrm{COCs}$ were cultured for $48 \mathrm{~h}$ in TCM-199 with $10 \%$ heat-inactivated follicular fluid and $1 \mu \mathrm{g} / \mathrm{ml} \mathrm{FSH}$ in $5 \%$ $\mathrm{CO}_{2}$ at $39^{\circ} \mathrm{C}$. The developmental capacity (progression to M-II stage) as assessed by aceto-orcein staining was $0,4.2,29.2$, and $86.6 \%$, respectively $\left(\mathrm{P}_{1.2}<0.01 ; \mathrm{P}_{2-3.3 .4 .2 .4}<0.001\right)$. 


\section{INTRODUCTION}

Data on cryopreservation of porcine oocytes are limited. Recent experiments on vitrification of this cell after polarization and removal of cytoplasmic lipids have had a certain degree of success (Nagashima et al., 1996). It must not, however, be forgotten that intracellular lipids are known to be a source of oocyte energy (Leninger, 1972) and, moreover, that oocyte lipids are important building materials for cytoplasmic membranes of future embryos. From this point of view the question of cryopreservation of porcine oocytes without removal of lipids is a very relevant one.

It is also known that osmotic injuries due to water outflow during previtrification treatment of bovine blastocysts are the most common. This damage may be decreased by step-wise equilibration of embryos in vitrification solution (Kuwayama et al., 1994).

Cytoskeletal relaxants Cytochalasin B and D have a specific, reversible effect on cytoskeletal elements. This effect is reflected in the depolimerization of the cytoskeleton, making it more flexible and pliable (Casella et al., 1981). The properties of these substances may be useful in the cryopreservation of cells in the prevention of deformation to cytoskeletal structures during cryopreservation.

Our investigations were designed to investigate the effect of single-step and step-wise cryoprotectant saturation by pre-treatment of GV-porcine oocytes vitrified without polarization or removal of cytoplasmic lipids.

\section{MATERIAL AND METHODS}

\section{Collection of oocytes}

For the collection of cumulus-oocyte complexes (COC), ovaries were taken from prepubertal gilts at a local abattoir and were transported to the laboratory in a prewarmed $\left(30-32^{\circ} \mathrm{C}\right)$ thermos within $2 \mathrm{~h}$. All ovaries were washed twice in $0.9 \% \mathrm{NaCl}$. Follicles between 2 and $5 \mathrm{~mm}$ in diameter were punctured with a short bevelled 18-gauge needle connected to a $5-\mathrm{ml}$ syringe at room temperature. The aspirates were placed in $10-\mathrm{ml}$ conical plastic tubes for $20 \mathrm{~min}$ at $39^{\circ} \mathrm{C}$ for sedimentation. Subsequently, the supernatant was removed and the remaining $2 \mathrm{ml}$ were transferred into $100 \mathrm{~mm}$ Petri dishes. COCs were collected under a stereomicroscope at $50 \mathrm{x}$ magnification and washed twice in HEPES buffered TCM 199 (Sigma Chemical Co., St.Louis, MO), supplemented with $2.2 \mathrm{~g} / 1 \mathrm{NaHCO}_{3}, 7 \%$ FCS (Sigma) and $50 \mathrm{mg} / \mathrm{l} \mathrm{Gentamicin} \mathrm{(Sigma).} \mathrm{Intact} \mathrm{COCs} \mathrm{with} \mathrm{at} \mathrm{least} 3$ layers of nonexpanded cumulus cells and an evenly granulated cytoplasm were used for investigations. Four hundred and sixty-nine COCs were used in three series of experiments. 


\section{Effect of stepped cryoprotectant saturation/ dilution without cooling}

In series I of the experiments, $150 \mathrm{COCs}$ were divided into 4 treatment and 1 control groups (Table 1). For single-step cryoprotectant saturation, COCs were exposed to $40 \%$ ethylene glycol (EG, Sigma) for $5 \mathrm{~min}$. For gradual saturation, COCs were exposed to $5,10,15,20,25,30$ and $40 \% \mathrm{EG}$ for 5,2, $2,2,1,0.5$ and $0.5 \mathrm{~min}$, respectively. For single-step cryoprotectant dilution, COCs were exposed to $0.75 \mathrm{M}$ sucrose (Sigma) for $9 \mathrm{~min}$. Step-wise dilution was performed with $\mathrm{COC}$ exposure to $1.0 \mathrm{M}, 0.75 \mathrm{M}, 0.5 \mathrm{M}$ and $0.25 \mathrm{M}$ sucrose for $4,2,2$, and $2 \mathrm{~min}$, respectively. Group 5 were control (not exposed to EG) COCs. Each experimental subgroup included $6 \mathrm{COCs}$, all tests were performed in 5 replications.

\section{Effect of cytoskeletal relaxant without cooling}

Series II of experiments was performed taking into account the results of series I experiments. The effect of a cytoskeletal inhibitor on cryoprotectant saturation/ dilution using single-step and step-wise procedures at $42^{\circ} \mathrm{C}$ was studied. One hundred COCs were divided into 2 treatment and 1 control groups (Table 2). Regimes of single-step or step-wise cryoprotectant saturation/dilution were as for experiments in series I. Experimental group 2 and control (group 3) COCs were additionally treated with $5 \mu \mathrm{g} / \mathrm{ml}$ Cytochalasin B (Sigma) for $10-15 \mathrm{~min}$ at $38.5^{\circ} \mathrm{C}$ prior to EG saturation. Each experimental subgroup included from 3 to $7 \mathrm{COC}$, all tests were performed in 6 replications.

\section{Effect of stepped cryoprotectant saturation on vitrification}

In Experiment III, performed taking into account the results of Experiments I and II, a total of 177 COCs were divided into three treatment and one control groups. All treatment COCs were vitrified after pretreatment with Cytochalasin B $\left(5 \mu \mathrm{g} / \mathrm{ml}\right.$ at $38.5^{\circ} \mathrm{C}$ for $10-15 \mathrm{~min}$ ), direct plunging into liquid nitrogen, thawing for $5 \mathrm{sec}$ in a waterbath at $50^{\circ} \mathrm{C}$, removal of the cryoprotectant by exposure to $1 \mathrm{M}$, $0.75 \mathrm{M}, 0.5 \mathrm{M}, 0.25 \mathrm{M}$ for $4,2,2$, and $2 \mathrm{~min}$, respectively at $40-42^{\circ} \mathrm{C}$. Group 1 COCs $(n=52)$ were vitrified after exposition in $40 \% \mathrm{EG}$ for $4 \mathrm{~min}$. Group $2 \mathrm{COCs}$ $(n=47)$ were exposed to $25 \% \mathrm{EG}$ for $5 \mathrm{~min}$ and then to $40 \% \mathrm{EG}$ for $30 \mathrm{sec}$ prior to direct plunging into liquid nitrogen. Group 3 COCs $(n=48)$ were equilibrated over 13 min using a series of EG concentrations $5,10,15,20,25,30$ and $40 \%$ EG for $5,2,2,2,1,0.5$ and $0.5 \mathrm{~min}$, respectively. Group 4 COCs $(\mathrm{n}=30)$ were control oocytes (not exposed to EG and not cooled). Each experimental subgroup included from 5 to $9 \mathrm{COC}$, all tests were performed in 6 replications. 
Cultivation and viability evaluation

After treatment, or without treatment (control), all COCs were cultured for $48 \mathrm{~h}$ in $5 \% \mathrm{CO}_{2}$ at $39^{\circ} \mathrm{C}$ in a humidified atmosphere. Microdrops of $50 \mu \mathrm{l}$ of the maturation media (HEPES buffered TCM 199, supplemented with $2.2 \mathrm{~g} / 1$ $\mathrm{NaHCO}_{3} ; 10 \%$ heat inactivated follicular fluid; $1 \mathrm{mg} / \mathrm{ml} \mathrm{FSH}$ and $50 \mathrm{mg} / \mathrm{l} \mathrm{Gentamicin)}$ were used. After incubation, COCs were denuded mechanically with a fine glass pipette, fixed in acetic acid ethanol $(1: 3 \mathrm{v} / \mathrm{v})$, stained after $24 \mathrm{~h}$ with $1 \%(\mathrm{w} / \mathrm{v})$ acetoorcein, and evaluated under a light microscope $(\mathrm{x} 400)$ for nuclear maturation.

\section{Statistical analysis}

All variances were analyzed for normality and homogeneity using the Kolmogorov-Smirnov and Bartlett tests to analyze normality of variances. If data satisfied these assumptions ANOVA was used, followed by LSD test with the Bonferroni adjustment. Otherwise, the Mann Whitney- $U$ test was employed. Differences were considered significant at $\mathrm{P}<0.05$.

\section{RESULTS}

\section{Effect of stepped cryoprotectant saturation/dilution without cooling}

The results of series I experiments (Table 1) indicate that the minimum values of developing oocytes $(53.3 \%)$ were obtained using the single-step protocol of cryoprotectant saturation/dilution. The maximum COC development rate was observed after performing these manipulations using the step-wise protocols of saturation and dilution (90\%).

TABLE 1

Effect of single-step and step-wise cryoprotectant saturation/dilution on viability of non-cooled GV-porcine oocytes by $42^{\circ} \mathrm{C}$ ( 1 series of experiments)

\begin{tabular}{lcccc}
\hline COC group & $\mathrm{n}$ & EG saturation * & EG dilution * & $\begin{array}{c}\text { Development of } \\
\text { ocytes to M-II stage, } \\
\mathrm{n}(\%)\end{array}$ \\
\hline 1 & 30 & single-step & single-step & $16(53.3)^{\mathrm{a}}$ \\
2 & 30 & single-step & step-wise & $18(60.0)^{\mathrm{a}}$ \\
3 & 30 & step-wise* & single-step & $25(83.3)^{\mathrm{b}}$ \\
4 & 30 & step-wise & step-wise & $27(90.0)^{\mathrm{b}}$ \\
5 (control) & 30 & - & - & $28(93.3)^{\mathrm{b}}$ \\
\hline
\end{tabular}

different superscripts indicate statistical differences $(\mathrm{P}<0.01)$

* described in text 
TABLE 2

Effect of cytoskeletal inhibitor on non-cooled GV-porcine oocytes after saturation and dilution of cryoprotectant using single-step and step-wise procedures at $42^{\circ} \mathrm{C}$ (II series of experiments)

\begin{tabular}{lccccc}
\hline COC group & $\mathbf{n}$ & $\begin{array}{c}\text { Pre-treatment with } \\
\text { Cytochalasin B* }\end{array}$ & $\begin{array}{c}\text { EG } \\
\text { saturation* }\end{array}$ & $\begin{array}{c}\text { EG } \\
\text { dilution* }\end{array}$ & $\begin{array}{c}\text { Development of } \\
\text { oocytes to M-II stage, } \\
n(\%)\end{array}$ \\
\hline 1 & 40 & no & step-wise* & step-wise & $33(82.5)$ \\
2 & 40 & yes & step-wise & step-wise & $34(84.9)$ \\
3 (control) & 20 & yes & - & - & $18(88.8)$ \\
\hline
\end{tabular}

any differences are not statistically significant $(\mathrm{P}>0.1)$

* described in text

\section{Effect of cytoskeletal relaxant without cooling}

The results of series II experiments (Table 2) demonstrate that the cytoskeletal inhibitor Cytochalasin B has no effect on the developmental rate of non-vitrified GV-porcine oocytes.

\section{Effect of stepped cryoprotectant saturation on vitrification}

In accordance with previous data we have defined the use of step-wise cryoprotectant saturation/dilution at $42^{\circ} \mathrm{C}$ and pretreatment with Cytochalasin $\mathrm{B}$ as a protocol for analyzing the effect of step-wise saturation in EG on GV-porcine oocyte vitrification. A positive effect of step-wise saturation was detected when EG was included in the protocol of COC vitrification (series III experiments, Table 3). Treatment with this substance allowed the proportion of viable vitrified oocytes to increase from 0 or 4.2 to $29.2 \%(\mathrm{P}<0.01)$.

TABLE 3

Effect of 1-, 2-, and 7-step saturation in EG on vitrification of porcine oocytes

\begin{tabular}{lccc}
\hline COC group & $\mathrm{n}$ & EG equilibration* & $\begin{array}{c}\text { Development of oocytes to M-II stage, } \\
\mathrm{n}(\%)\end{array}$ \\
\hline 1 & 52 & single-step & $0(0.0)^{\mathrm{a}}$ \\
2 & 47 & two-step & $2(4.2)^{\mathrm{b}}$ \\
3 & 48 & step-wise & $14(29.2)^{\mathrm{c}}$ \\
4 (control) & 30 & - & $26(86.6)^{\mathrm{d}}$ \\
\hline
\end{tabular}

different superscripts indicate statistical differences $(\mathrm{P}<0.01)$

* described in text 


\section{DISCUSSION}

The earliest approaches to mammalian oocyte and embryo cryopreservation by direct plunging into liquid nitrogen only consider the use of permeable cryoprotectants (vitrification) or permeable cryoprotectants in combination with non-permeable crystal-forming ones (rapid- or ultra-rapid freezing) for saturation before plunging into liquid nitrogen. The main objective of vitrification is to achieve full binding of intracellular water and, therefore, complete prevention of ice formation. Further experimental work has changed these notions. A number of studies have suggested that full binding of extra- and intracellular water is not necessary for cell vitrification (Leibo and Oda, 1993). This was pointed out with the introduction of crystal-forming (osmotically active) cryoprotectants into the vitrification medium, or using short time exposure of cells to the vitrification medium containing only permeable cryoprotectants, before plunging into liquid nitrogen. Notwithstanding, we have obtained preliminary results (unpublished data) showing that for follicular porcine and bovine oocytes it is necessary to obtain full binding of intracellular water before oocyte cooling. The protocol for vitrification of these oocytes must include the following parameters: step-wise saturation of cells with permeable cryoprotectant(s); use of cryoprotectant(s) with good permeable properties; exclusion of crystal forming cryoprotectant(s) from vitrification medium; use of increased temperature for saturation and removal of cryoprotectant(s) and also for thawing; use of cytoskeletal relaxant to prevent cytoskeletal deformations. This was the basis for the present experimental design. EG was chosen as the cryoprotective agent from a number of popular cryoprotectants (DMSO, propylene glycol, glycerol). Only DMSO has more pronounced permeable properties than EG, but DMSO is a more toxic cryoprotectant than EG: with the use of the described vitrification regime, including long exposure to vitrification medium at increased temperature, the parameter "toxic effect of cryoprotectant" becomes more relevant.

Kuwayama et al. (1994) reported high survival rates of bovine blastocysts after vitrification using a 16-step method of saturation of embryos with permeable cryoprotectants. In contrast, survival was very low when equilibration was performed in 2-steps. The freezing-fracture electron micrographs of blastocysts treated by the 2-step and the 16-step methods both show absence of intra- and extracellular crystallization after plunging into liquid nitrogen. However, there are distinct ultrastructural changes to the plasma membrane in the blastocysts treated by the 2 -step method. The electron micrographs did not show these ultrastructural changes when using the 16-step cryoprotectant saturation. The authors suggest that the lethal injury to blastocysts undergoing vitrification was not caused by crystal formation during cooling. Instead, they believe that osmotic injury to cells occurred in the blastocysts due to osmotic processes accompanying saturation with perme- 
able cryoprotectants. The results obtained in the present study support this conclusion as regards porcine follicular oocytes (Table 1). Experiments in this series could be interpreted as follows: osmotic processes accompanying saturation and dilution of cryoprotectant are the most significant destructive factor. In the experiments of Kuwayama et al. (1994), full saturation of blastocysts with permeable cryoprotectants in 16 steps was performed. This fact is reflected in the following: after 16-step equilibration to cryoprotectants the blastocysts have a noncollapsed form before being plunged into liquid nitrogen that suggests full saturation of cells by permeable cryoprotectants. In contrast, shrinkage of embryos was observed with equilibration by the 2-step method. For removal of these cryoprotectants, exposure to a non-permeable cryoprotectant (1M sucrose) was used. We suppose that the osmotically active dehydration process accompanying the saturation of blastocysts with permeable cryoprotectants is analogous to that which occurs during cryoprotectant dilution. This osmotic negative effect is not, however, particularly significant as an after-effect of the osmotic process of saturation with cryoprotectants (previtrification treatment). Results obtained in series I experiments demonstrated the positive effect of the "step-wise cryoprotectant dilution" parameter on vitrification of porcine oocytes, but only when using an elevated temperature and step-wise EG saturation.

Thus, added in a regime of pre- and postvitrification treatment, the parameters „step-wise cryoprotectant saturation and dilution” and ,pretreatment with Cytochalasin B" resulted in a developmental rate of follicular oocytes commensurable with that of non-treated oocytes. Also, these data show that the factor of "toxicity of cryoprotectants" which has been studied in detail in many works on vitrification of embryos and oocytes is a secondary one.

Nagashima et al. (1996) have obtained embryos from GV-porcine oocytes which were vitrified following delipidization. Using this method the authors avoided a negative after-effect caused by the cooled intracellular lipids. According to the data provided by the authors, removal of intracellular lipids does not lead to a worsening of further development of oocytes and embryos. Successful oocyte vitrification after removal of cytoplasmic lipids leads to the question of changes in the physico-chemical properties of cytoplasmic membrane lipids arising at low temperatures (Quinn, 1986) being discounted as a significant cause of cryobiological problems for the terms of our experiments. We do, however, believe that it is impossible to dismiss classic data about the role of intracellular lipids as energetic materials of oocytes (Leninger, 1972) and building materials for membranes of future embryos. The fact that the volume of mitochondria as well as lipid vesicles increases during oocyte development to M-II stage (Dvorak, 1989) indirectly confirms this. Moreover, Sathananthan et al. $(1992,1994)$ have shown that in the cell complex ,smooth endoplasmatic reticulum-lipid globules-mitochondria" there are reticulum- 
globules-mitochondria connections. They have also shown that these connections may be destroyed after oocyte cooling or freezing.

Many publications on problems of mammalian oocyte cryopreservation contain information on the negative effects of low temperature including the cytoskeleton depolimerization effect of permeable cryoprotectants (Johnson and Pickering, 1987; Aigner et al., 1992; Joly et al., 1992). We believe that the negative effect of cooling on porcine oocytes may be explained by way of the effect of cooling lipids on cytoskeletal structures. While performing our preliminary investigations, we found that following centrifugation, redistribution of lipids occurs within $48 \mathrm{~h}$ of in vitro culture in oocytes not exposed to freeze/thawing. However, when polarized oocytes are freeze/thawed, the lipid polarization is irreversible. This, in our opinion, suggests that the freeze/thaw process induces an alteration in the physico-chemical properties of intracellular lipids. It is known that M-II oocytes are more resistant to freeze damage than GV-stage oocytes. We consider that this may be due to differences in the properties of cytoskeletal elements. One important difference is that the configuration of microtubules and microfilaments is different at these two stages of oocyte maturation. Cytoskeleton elements in $\mathrm{GV}$-oocytes appear straight and rigid, while the appearance of microfilaments and microtubules in M-II stage oocytes is undulating and flexible (Allworth and Albertini, 1993). On the hypothesis that the interaction between the lipid phase of cells and the elements of the cytoskeleton is complex, hardening of these lipids might cause deformation and disruption of the cytoskeleton. In the case of the rigid GV-oocyte cytoskeleton this apparently results in permanent damage while in the more flexible M-II-oocyte cytoskeleton, permanent damage is absent. Cytochalasin B has a specific, reversible effect on microtubules, microfilaments (Casella et al., 1981) and other cytoskeletal elements making them more flexible and less susceptible to cryo-damages. This was our reason for testing this substance for the vitrification of GV-porcine oocytes.

Therefore, on the one hand the lipids are a "stumbling-block" during oocyte cryopreservation, but, on the other hand, their role in the vital activity of cells as energetic and building materials is important. In order for GV-porcine oocytes to be successfully vitrified, it can be speculated that it is necessary to achieve the following conditions: (1) prevention of alterations to the physico-chemical properties of cooled lipids; (2) avoidance of irreversible damage to the lipid globule membranes; (3) protection of the reticulum-lipid connections from destruction. Further investigations will test the validity of these conditions.

It is known (Ealy et al., 1993) that high temperature has a detrimental effect on the embryonic development of many mammals, including pigs (Warnick et al., 1965; Tompkins et al., 1967; Omtvedt et al., 1971). When cultured cells are affected by elevated temperatures, they respond by synthesizing heat-shock proteins (Linquist, 1986). An acquisition of embryo thermotolerance is related to these 
proteins synthesized (Howell et al., 1994), and according to more recent data, they can precede thermotolerance of cells (Hahnel et al., 1986; Morange et al., 1995). At present these proteins are the object of study by a number of researchers. Recently Kojima et al.(1996) have examined the effect of elevated temperature on the developmental rate of porcine embryos. Synthesis of $70 \mathrm{kDa}$ and $90 \mathrm{kDa}$ heatshock proteins was also determined. The authors have shown that exposure of embryos to 42 to $45.5^{\circ} \mathrm{C}$ has impaired their survival, as assessed by the difference in the number of viable nuclei. No increase of $70 \mathrm{kDA}$ and $90 \mathrm{kDA}$ was, however, observed in heat-stressed embryos. It is noted that the precise mechanism of thermotolerance was unclear. The authors of this publication suppose that the increased development of embryos following acute temporary elevation in ambient temperature may be associated with a constitutive production of $70 \mathrm{kDa}$ heat-shock proteins. We offer an explanation of the described phenomenon of the effect of elevated temperature on porcine embryos (Kojima et al., 1996) from the angle of the effect on intracellular lipids. We believe that low temperatures have a negative influence on intracellular lipids of the oocyte as well as of porcine embryos. This influence induces the alteration of their physico-chemical properties. Possibly, the opposite deviation of the physiological temperature (to increasing) may have a positive effect. The increase of developmental rate of the porcine embryos exposed to $42-45.5^{\circ} \mathrm{C}$ reported by Kojima et al. (1996) may be explained through „positive" alterations to intracellular lipids. These ,positive" alterations could compensate a further negative cryo-effect of cryopreservation on cooled oocytes. In this way, a positive influence of intracellular antioxidants on cryopreservation of cells (Tarin and Trounson, 1993; Zeron and Arav, 1996; Zeron et al., 1997) can also be explained since it is known that antioxidants protect cell lipids from negative alterations to their physico-chemical properties (Cadenas et al., 1981; EklowLastbom et al., 1986, as review).

It is known that bovine oocytes are to a considerable extent more cryostable than porcine oocytes. There is also information to suggest that the diameters of bovine and porcine vesicles are different. The question of possibility of lipid vesicle diameter of being a reflection of the physico-chemical properties of lipids and cryostable properties of oocytes of the same breed and between breeds and of the storage rate of intracellular lipid vesicles as a criterion for the effectiveness of the testing cryopreservation regime are interesting. The matter of the character of the intracellular lipid granule membranes is also topical.

We do not regard the described plan of cryopreservation as a definitive proto$\mathrm{col}$, it is suggested as a direction for further investigations into the cryopreservation of GV-porcine oocytes and other lipid-rich cells. 


\section{ACKNOWLEDGEMENTS}

These investigations were supported by the Alexander von Humboldt Foundation. This work was presented in part at the CRYO'96 meeting (Indianapolis, USA) and at the 1996 A.E.T.E. meeting (Lyon, France). The authors gratefully acknowledge Mr.I.V. Costello for linguistic assistance.

\section{REFERENCES}

Aigner S., Van der Elst J., Siebzehnruebl E., Wild L., Lang N., Van Seirteghem A.C., 1992. The influence of slow and ultra-rapid freezing on the organization of the meiotic spindle of the mouse oocytes. Human Reprod. 7, 857-867

Allworth A.E, Albertini D.F., 1993. Meiotic maturation in cultured bovine oocytes is accompanied by remodeling of the cumulus cell cytoskeleton. Develop. Biol. 158, 101-112

Cadenas E., Weffers H., Sies H., 1981. Low-level chemiluminescence of isolated hepatocites. Eur. J. Biochem. 119, 531-536

Casella J., Flanagan M., Lin S., 1981. Cytochalasin D inhibits actin polymerization and induces depolimerization of actin filaments formed during platelet shape change. Nature 293, 302-305

Dvorak M., 1989. Ultrastructure and quantitative analysis of mouse and human oocytes. In: Liss A.R. (Editor). Developments in ultrastructure of reproduction. New York, pp. 273-280

Ealy A.D., Drost M., Hansen P.J., 1993. Developmental changes in embryonic resistance to adverse effects of maternal heat stress in cows. J. Dairy Sci. 76, 2899-2905

Hahnel A.C., Gifford D.J., Heikkila J.J., Schultz G.A., 1986. Expression of the major heat shock protein (hsp 70) family during early mouse embryo development. Teratogen Carcino. Mut. 6, 493-510

Howell J.L., Ealy A.D., Monterroso V.H., Hansen P.J., 1994. Synthesis of heat shock protein 70 in preimplantation murine and bovine embryos. J. Anim. Sci. 72, Suppl. 1, abstr. 79

Johnson M.H., Pickering S.J., 1987. The effect of dimethylsulfoxyde on the microtubular system of the mouse oocyte. Development 100, 313-324

Joly C., Bchini O., Boulekbache H., Testart J. Maro B., 1992. Effect of 1,2-propanediol on the cytoskeletal organization of the mouse oocytes. Human Reprod. 7, 374-378

Kojima T., Udagawa K., Onishi A., Iwahashi H., Komatsu Y., 1996. Effect of heat-stress on development in vitro and in vivo and on synthesis of heat shock proteins in porcine embryos. Mol. Reprod. Dev. 43, 452-457

Kuwayama M., Fujikawa S., Nagai T., 1994. Ultrastructure of IVM-IVF bovine blastocysts vitrified after equilibration in glycerol, 1.2-propanediol using 2-step and 16-step procedures. Cryobiology $31,415-422$

Leibo S.P., Oda K., 1993. High survival of mouse zygotes and embryos cooled rapidly or slowly in ethylene glycol plus polyvinylpyrrolidone. Cryo Lett. 14, 134-144

Lehninger A.L., 1972. Biochemistry: The Molecular Basis of Cell Structure and Function. New York, Worth Publishers, pp. 960

Lindquist S., 1986. The heat-shock response. Ann. Rev. Biochem. 55, 1151-1191 
Morange M., Diu A., Bensaude O., Babinet C., 1984. Altered expression of heat shock proteins in embryonal carcinoma and mouse early embryonic cells. Mol. Cell. Biol. 4, 730-735

Nagashima H., Kuwayama M., Grupen C.G., Ashman R.J., Nottle M.B., 1996. Vitrification of porcine early cleavage stage embryos and oocytes after removal of cytoplasmic lipid droplets. Theriogenology 45 , abstr 180

Omtvedt I.T., Nelson R.E., Edwarrds R.L., Stephens D.F., Turman E.J., 1971. Influence of heat stress during early, mid and late pregnancy of gilts. J. Anim. Sci. 32, 312-317

Quinn P., 1989. Principles of membrane stability and phase behavior under extreme conditions. J. Bioenerg. Biomembr. 21, 3-19

Sathananthan A.H., 1994. Ultrastructural changes during meiotic maturation in mammalian oocytes: Unique aspects of the human oocyte. Micr. Res. Techn. 27, 145-164

Sathananthan A.H., Kirby C., Peura A., Trounson A., 1992. Mouse oocyte cooling. J. Assist. Reprod. Genet. 9, 139-148

Tarin J.J., Trounson A.O., 1993. Effect of stimulation or inhibition of lipid peroxidation on freezingthawing of mouse embryos. Biol. Reprod. 49, 1362-1368

Tompkins E.C., Meidenreich C.J., Stob M.,1967. Effect of post-breeding thermal stress on embryonic mortality in swine. J. Anim. Sci. 26, 377-380

Warnick A.C., Wallace H.D., Palmer A.Z., Sosa E., Duerre D.J., Caldwell V.E., 1965. Effect of temperature on early embryo survival in gilts. J. Anim. Sci. 24, 89-92

Zeron Y., Arav A., 1996. The effect of butylated hydroxytoluene (BHT) on the viability of immature bovine oocytes after cold storage. Theriogenology 45 , abstr. 163

Zeron Y., Arav A., Krowe J.H., 1997. The effect of butylated hydroxytoluene (BHT) on the lipid phase transition in immature and mature bovine oocytes. Theriogenology 47, abstr. 362

\section{STRESZCZENIE}

Witryfikacja oocytów świnskich (w stadium pęcherzyka zarodkowego) przy zastosowaniu jedno-, dwu i siedmiostopniowego wysycania glikolem etylenowym

Przeprowadzono trzy doświadczenia nad efektywnością jedno-, dwu- i siedmiostopniowego wysycania oocytow świńskich glikolem etylenowym na ich witrifikację, od stadium wczesnego rozwoju do stadium metafazy II (M-II).

W pierwszym doświadczeniu niemrożony cummulus-oocyte kompleks $\left(\mathrm{COC}_{\mathrm{s}}\right)$ stabilizowano w glikolu etylenowym (EG), jedno- lub wielokrotnie, następnie glikol usuwano - podobnie jednolub wielokrotnym zabiegiem, przeprowadzając wszystkie manipulacje $w$ temperaturze $42^{\circ} \mathrm{C}$. W doświadczeniu drugim postępowano podobnie z tym, że przed usunięciem glikolu $\mathrm{COC}_{\mathrm{s}}$ traktowano cytochalazyną $B$.

W doświadczeniu trzecim, uwzględniając wyniki pierwszego i drugiego doświadczenia, wszystkie oocyty (177) podzielono na 4 podgrupy, w tym 3 doświadczalne i 1 kontrolną. Przed mnożeniem wszystkie oocyty traktowano cytochalazyną $\mathrm{B}(5 \mu \mathrm{g} / \mathrm{ml})$ przy $38^{\circ} \mathrm{C}$ przez $10-15 \mathrm{~min}$, po czym rozmrażano przez 5 sek w łaźni wodnej w $50^{\circ} \mathrm{C}$, następnie usuwano glikol etylenowy używając roztworu sacharozy w stężeniu $1 ; 0,75 ; 0,5$ i $0,25 \mathrm{M}$, odpowiednio przez $4,2,2$ i 2 min. w temp. $40-42^{\circ} \mathrm{C}$. W podgrupie 1 oocyty $(n=52)$ witryfikowano po wcześniejszym traktowaniu $40 \%$ gliko- 
lem przez 4 min. W podgrupie 2 oocyty $(n=47)$ poddano działaniu $25 \%$ roztworu glikolu przez 5 min, a następnie $40 \%$ glikolem etylenowym przez 30 sek i przenoszono do ciekłego azotu. W podgrupie 3 oocyty $(n=48)$ przed zamrożeniem były stabilizowane przez $13 \mathrm{~min} 40 \%$ glikolem etylenowym w różnych stężeniach: $5,10,15,20,25,30$ i $40 \%$ przez $5,2,2,2,1,05$ i 0,5 min, odpowiednio. W podgrupie 4 , kontrolnej, oocyty $(n=30)$ nie były poddane działaniu glikolu ani nie były zamrażane. Po rozmrożeniu i traktowaniu sacharozą oocytów podgrup doświadczalnych oraz grupy kontrolnej oocyty przenoszono na 48 godz do medium 199 z dodatkiem inaktywowanego płynu pęcherzykowego i FSH $(1 \mu \mathrm{g} / \mathrm{ml})$ w atmosferze $5 \% \mathrm{CO}_{2}$ w temp. $39^{\circ} \mathrm{C}$.

Stwierdzono, że zdolność rozwoju (osiągnięcia stadium M-II) zależała od sposobu wirtyfikacji i występowała u $0 ; 4,2 ; 29,2$ i 86,6\% oocytów $\left(\mathrm{P}_{1-2}<0,01 ; \mathrm{P}_{2-3,3-4,2-4}<0,001\right)$, odpowiednio w grupach 1,2 i 3 oraz w grupie kontrolnej. 